\title{
Effectiveness of xylanase and Saccharomyces cerevisiae as feed additives on gas emissions from agricultural calf farms
}

\author{
Agustín Hernández ${ }^{a}$, Ahmed E. Kholif ${ }^{\mathrm{b}}$, Mona M.M.Y. Elghandour ${ }^{\mathrm{a}}$, Luis M. Camacho ${ }^{\mathrm{c}}$, \\ Moisés M. Cipriano ${ }^{c}$, Abdelfattah Z.M. Salem ${ }^{\text {a, }}{ }^{*}$, Humberto Cruz ${ }^{a}$, Eziuche A. Ugbogu ${ }^{d}$ \\ ${ }^{a}$ Facultad de Medicina Veterinaria y Zootecnia, Universidad Autónoma del Estado de México, Mexico \\ b Dairy Science Department, National Research Centre, 33 Bohouth St., Dokki, Giza, Egypt \\ ${ }^{\mathrm{c}}$ Unidad Académica de Medicina Veterinaria y Zootecnia, Universidad Autónoma de Guerrero, Km. 3.5 Carretera Cd. Altamirano-Iguala, CP 40660, Cd. \\ Altamirano, Guerrero, Mexico \\ d Department of Biochemistry, Abia State University, P.M.B 2000, Uturu, Abia State, Nigeria
}

\section{A R T I C L E I N F O}

\section{Article history:}

Received 19 September 2016

Received in revised form

12 January 2017

Accepted 12 January 2017

Available online 17 January 2017

\section{Keywords}

Carbon dioxide

Methane

S. cerevisiae

Sustainable control

Xylanase

\begin{abstract}
A B S T R A C T
The aim of the present study was to evaluate the potential of supplementing calves' diets with exogenous enzymes (xylanase; $\mathrm{XYL}$ ) and yeast (Saccharomyces cerevisiae [SC]) on the sustainable control of methane $\left(\mathrm{CH}_{4}\right)$ and carbon dioxide $\left(\mathrm{CO}_{2}\right)$ productions in agricultural calves farming. Three different levels of supplemented diets of XYL (0, 3 and $6 \mathrm{mg} / \mathrm{g}$ of dry matter (DM)), SC (0, 2 and $4 \mathrm{mg} / \mathrm{g}$ of DM) and mixture of XYL and SC ( $0,2 \mu \mathrm{L} \mathrm{XYL}+2 \mathrm{mg} \mathrm{SC}, 6 \mu \mathrm{L} \mathrm{XYL}+4 \mathrm{mg} \mathrm{SC} / \mathrm{g}$ of DM) were tested. Asymptotic gas production (GP) consistently decreased by each of the additives with the lowest value at the high dose of $\mathrm{XYL}+\mathrm{SC}$ mixture $(P<0.05)$ compared with the control and the low dose of XYL + SC mixture. Methane production was reduced by additives inclusion $(P<0.05)$ when compared with the control treatment with no additive. Xylanase $+\mathrm{SC}$ at all doses increased $\mathrm{CO}_{2}$ production $(P<0.05)$ whereas the high dose had the most statistically significant $(P<0.05)$ reduction in GP and $\mathrm{CH}_{4}$ production compared with control, XYL and SC additives at different doses. Interaction between additive and rumen liquor was observed for rate of GP $(P=0.027)$ and initial delay before GP $(P<0.001)$. Inclusion of XYL, SC, and $\mathrm{XYL}+\mathrm{SC}$ mixture had less asymptotic GP while XYL + SC mixture had the lowest initial delay (39\%) before GP began. The XYL + SC had the lowest rate of $\mathrm{CH}_{4}$ production (9\%) and highest asymptotic $\mathrm{CO}_{2}$ production (81\%). The findings of this study indicate that inclusion of XYL or SC additives can improve rumen fermentation and reduce greenhouse gases production. The study also established that the mixture of $\mathrm{XYL}$ and $\mathrm{SC}$ is more efficient in reducing gas and $\mathrm{CH}_{4}$ emissions for cleaner environmental production conditions in calf farming.
\end{abstract}

() 2017 Elsevier Ltd. All rights reserved.

\section{Introduction}

Worldwide, agricultural farming systems, such as livestock production, face the increasing challenge of maintaining future global demand for meat and dairy products because of an expected increase in population (Wiedemann et al., 2017). The Food and Agriculture Organization (FAO, 2006) expects that an increase in purchasing power for food from animal sources raises the yearly demand to 465 and 1.043 million t for meat and milk products. Besides, the FAO estimates the growth of global population to reach 9.6 billion by the y 2050 (FAO, 2016), with a doubled purchasing power for meat and dairy products. To meet this rise in demand, agricultural systems need to devise a means to adapt to the probability of dangerous climate change and become more resilient, productive and sustainable (FAO, 2016). This will not only reduce greenhouse gas (GHG) emissions but also ensure the wellbeing of

Abbreviations: ADF, acid detergent fiber; $b$, the asymptotic gas, methane, or carbon dioxide production; $c$, the fractional rate of fermentation; $C F U$, colony-forming unit;

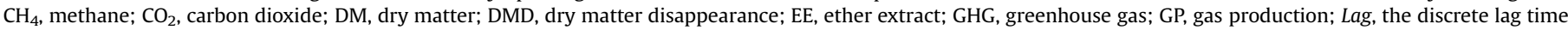
prior to any gas, $\mathrm{CO}_{2}$ or $\mathrm{CH}_{4}$ formation; NDF, neutral detergent fiber; SC, Saccharomyces cerevisiae; XYL, xylanase.

* Corresponding author.

E-mail address: asalem70@yahoo.com (A.Z.M. Salem). 
the ecosystem and rural populations.

Today, agricultural waste products are one of the largest contributors of anthropogenic sources of three major GHGs: methane $\left(\mathrm{CH}_{4}\right)$, carbon dioxide $\left(\mathrm{CO}_{2}\right)$, and nitrous oxide, with livestock production accounting for approximately two-thirds of the direct emissions (Slade et al., 2016), largely from digestion by livestock. Methane is the major GHG emitted from enteric fermentation through the typical digestive process of ruminants (Hristov et al., 2015). Methane accounts for approximately 12 to 17\% GHG emission (Beauchemin et al., 2009). However, the major constraints in ruminant farming include: excessive excretion of nutrients, inefficient digestibility and high $\mathrm{CH}_{4}$ emission which represent a net loss of 2 to $12 \%$ of gross dietary energy (Hristov et al., 2015). The efficient reduction of such energy losses may be potentially used for the production of more meat and milk, rather than contributing to GHG production which impacts negatively on climate change (Eckard et al., 2010). Recently, the use of exogenous enzymes (Rojo et al., 2015 ) and yeast (Saccharomyces cerevisiae; SC) additives in ruminant diets has attracted considerable interest (Hassan et al., 2016). Many research studies have shown that supplementing exogenous enzymes in livestock diets improved forage quality (Kholif et al., 2017), increase digestibility, rumen fermentation, and ruminant production (Valdes et al., 2015). However, Lewis et al. (1999) reported that exogenous enzymes did not consistently enhance forage quality and utilization by ruminants. This inconsistency may be attributed to several factors such as the source of the enzyme (Khattab et al., 2011), doses and activities of the enzyme (Jalilvand et al., 2008), physical properties of the substrate (Elghandour et al., 2015), treatment duration, enzyme application method (Elghandour et al., 2016a), composition of the diet to which enzyme is added (Elghandour et al., 2016a) and level of animal productivity (Beauchemin et al., 2003).

Animal nutritionists and microbiologists have recently developed keen interest in the use of dietary feed additives to modify ruminal fermentation and reduce rumen GHG production (Hernandez et al., 2017). Dick et al. (2015) reported that the use of legumes as a replacement for nitrogen fertilizer enhanced reduction of GHG emission. Nguyen et al. (2010) suggested that increasing the proportion of concentrate-based diet would reduce the $\mathrm{CH}_{4}$ production. Supplementation of SC improved digestibility of low quality forages and altered microbial environment by increasing the number of ruminal microflora which could enhance fiber fraction digestion in ruminants (Ahmed et al., 2015) and horses (Salem et al., 2016). Salem et al. (2015a) observed that inclusion of exogenous fibrolytic enzymes (e.g., cellulase and xylanase $(X Y L)$ ) improved feed utilization in ruminants. Exogenous XYL was selected to be studied in the present study because emerging evidences show better results with XYL than cellulase (Vallejo et al., 2016).

Few studies investigated the effect of natural feed additives on $\mathrm{CH}_{4}$ and GHG productions. The present study evaluated the use of exogenous enzyme (xylanase), yeast (S. cerevisiae) and their mixture, as dietary feed additives, to enhance the nutritive value of feeds and to mitigate the production of $\mathrm{CO}_{2}$ and $\mathrm{CH}_{4}$ from the agriculture calf farms using the in vitro gas production (GP) technique.

\section{Materials and methods}

\subsection{In vitro incubations and treatments}

Rumen inoculum was collected by stomach tube from 40 weaned Holstein calves (40-55 kg body weight) before morning feeding. They were divided into 4 groups $(n=10)$ which were fed a basal diet with no additive (Control rumen liquor), or daily supplemented with $5 \mathrm{~mL}$ of XYL (Dyadic PLUS; Dyadic international, Inc, Jupiter, FL, USA) [XYL rumen liquor], or $4 \mathrm{~g}$ of SC, with a minimum guaranteed concentration of live yeast cells of $1.5 \times 10^{10} \mathrm{CFU}$ of SC/g of product (Procreatin 7, Safmix, Toluca, Mexico) [SC rumen liquor] or their mixture ( $2.5 \mathrm{~mL} \mathrm{XYL}+2 \mathrm{~g} \mathrm{SC})$ (XYL + SC rumen liquor) for $60 \mathrm{~d}$ of age. All the 40 calves were stabled and reared under the same condition. The calves were fed ad libitum a total mixed ration of a commercial concentrate (Ultra Malta Clayton $^{\circledR}$, Toluca, Mexico) formulated to meet their nutrient requirements (NRC, 1985) with free access to fresh water. The diet contained per kg dry matter (DM) of $200 \mathrm{~g}$ crude protein, $230 \mathrm{~g}$ neutral detergent fiber (NDF), $50.3 \mathrm{~g}$ acid detergent fiber (ADF) and $35.6 \mathrm{~g}$ ether extract (EE). The treatments which were tested against control treatment (no additives) were as follows: XYL treatment (at 3 and $6 \mu \mathrm{L} / \mathrm{g} \mathrm{DM}$ ), SC treatment (at 2 and $4 \mathrm{mg} / \mathrm{g} \mathrm{DM}$ ) and their mixture at $3 \mu \mathrm{L} \mathrm{XYL}+2 \mathrm{mg} \mathrm{SC}$, and $6 \mu \mathrm{L} \mathrm{XYL}+4 \mathrm{mg} \mathrm{SC}(\mathrm{XYL}+\mathrm{SC}$ treatment). The diet fed to the calves was used as the substrate for the in vitro incubation. The product of XYL contained: 34,000 to $41,000 \mathrm{U}$ of $\mathrm{XYL} / \mathrm{mL}, 12,000$ to 15,000 units of beta-glucanase $/ \mathrm{mL}$, and 45,000 to $55,000 \mathrm{U}$ of cellulase $/ \mathrm{mL}$.

Immediately after collection, the rumen contents obtained from the donor calves were flushed with $\mathrm{CO}_{2}$, mixed and strained through four layers of cheesecloth into a flask with oxygen-free headspace. Filtered rumen fluid was immediately transported to the laboratory where it was mixed in a 1:4 (v/v) proportion with the buffer solution (containing micro- and macro-elements, a reducing agent and a reduction indicator of resazurin) as described by Goering and Van Soest (1970), with no trypticase added. Diluted rumen fluid ( $50 \mathrm{~mL}$ containing $10 \mathrm{~mL}$ of rumen liquor) was added to each incubation bottle of $120 \mathrm{~mL}$ containing $0.5 \mathrm{~g}$ of substrate, which had been previously weighed out and additive solutions dispensed.

Three incubation runs were performed in three different weeks. Bottles were inoculated within each incubation run, with three bottles as blanks (i.e., rumen fluid only with no substrate or additive). After filling all bottles, they were flushed with $\mathrm{CO}_{2}$ and immediately closed with rubber stoppers, shaken and placed in a water bath at $39^{\circ} \mathrm{C}$. The volume of gas produced was recorded at 2 , $4,6,8,10,12,14,16,18,24,36,48$ and $70 \mathrm{~h}$ of incubation using a pressure transducer (Extech Instruments, Waltham, USA) following the technique of Theodorou et al. (1994). At the same incubation times, $\mathrm{CH}_{4}$ and $\mathrm{CO}_{2}$ concentrations in the headspace of the bottles were measured using a diffusion based gas detector (Gas Analyzer CROWCON Model Tetra3, Abingdon, UK). The in vitro incubation process can be summarized in Fig. 1.

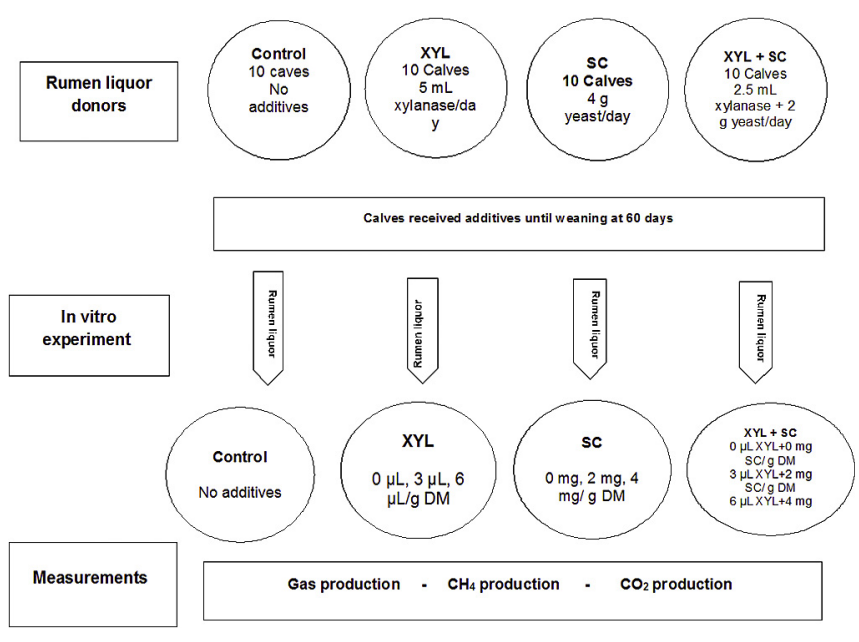

Fig. 1. Flowchart of the in vitro incubation process. 
After sampling the supernatant for $\mathrm{pH}$ determination, the contents of each bottle were filtered under vacuum through sintered glass crucibles (coarse porosity no. 1, pore size 100-160 $\mu \mathrm{m}$; Pyrex, Stone, UK). The incubation residues were then dried at $70{ }^{\circ} \mathrm{C}$ overnight to estimate apparent DM disappearance (DMD).

\subsection{Chemical analyses}

Samples of the incubated substrate were analyzed for DM (method ID 934.01), ash (method ID 942.05), nitrogen (method ID 954.01) and EE (method ID 920.39) using Association of Official Analytical Chemists (AOAC, 1997) official methods. The NDF (Van Soest et al., 1991) and ADF (AOAC, method ID 973.18) contents were determined using an ANKOM $^{200}$ Fiber Analyzer Unit (ANKOM Technology Corp., Macedon, NY, USA). The NDF analysis was done with sodium sulfite, and with $\alpha$-amylase. Both NDF and ADF were expressed without residual ash.

\subsection{Calculations and statistical analyses}

Volumes (mL/g DM) of gas, $\mathrm{CO}_{2}$, and $\mathrm{CH}_{4}$ were used to estimate the fermentation kinetic parameters using the NLIN procedure of Statistical Analysis System (SAS, 2002) according to France et al. (2000) model as:

$y=b \times\left[1-e^{-c(t-\operatorname{Lag})}\right]$

where $y$ is the volume of gas, $\mathrm{CO}_{2}$ or $\mathrm{CH}_{4}$ at time $t(\mathrm{~h}) ; b$ is the asymptotic $\mathrm{GP}, \mathrm{CO}_{2}$ or $\mathrm{CH}_{4}$ production ( $\mathrm{mL} / \mathrm{g} \mathrm{DM}$ ); $c$ is the fractional rate of fermentation (per $\mathrm{h}$ ), and $\operatorname{Lag}(\mathrm{h})$ is the discrete lag time prior to any gas, $\mathrm{CO}_{2}$ or $\mathrm{CH}_{4}$ formation.

The experimental design for the in vitro ruminal GP and fermentation parameters analysis was a completely randomized design, considering as fixed factors, additive type and additive doses in the linear model (Steel and Torrie, 1980). Data of each of the three runs within the same sample were averaged prior to statistical analysis. Mean values of each individual extract within each species (three samples of each) were used as the experimental unit. Multiple comparisons of means were performed using the Tukey's test. Significance was declared at a level of $P<0.05$.

\section{Results}

Fig. 2 shows the in vitro rumen GP $(\mathrm{mL} / \mathrm{g}$ incubated $\mathrm{DM})$ of a calf's diet, supplemented with XYL, SC, and XYL + SC mixture. Interaction between additive and rumen liquor was observed for rate of GP $(P=0.027)$ and initial delay before GP $(P<0.001$; Table 1$)$. No effect $(P>0.05)$ was noted between additive $\times$ dose for asymptotic GP, rate of GP and initial delay before GP. Inclusion of $\mathrm{XYL}, \mathrm{SC}$, and XYL + SC had a higher asymptotic GP while XYL + SC mixture had the lowest initial delay (39\%) before GP began. There was a decrease $(P<0.05)$ in the average asymptotic GP (at all doses) of the treatment XYL $+\mathrm{SC}$ mixture compared with the control treatment (no additive). The supplementation of XYL and SC to the diets of the calves had no statistically significant effects $(P>0.05)$ on the asymptotic GP at all tested doses, while the supplementation of a mixture of XYL + SC at a high dose affected it $(P<0.05)$ compared with the control. The rate of GP showed a positive effect $(P<0.05)$ on all the doses of XYL addition while no statistically significant effect $(P>0.05)$ was observed with the addition of SC and XYL + SC mixture additives, when compared with the control. In addition, there was an increase in the lag time of GP at each dose of XYL, SC and XYL + SC mixture (only at the high dose) additives, and a statistically significant effect $(P<0.05)$ on all the doses of XYL

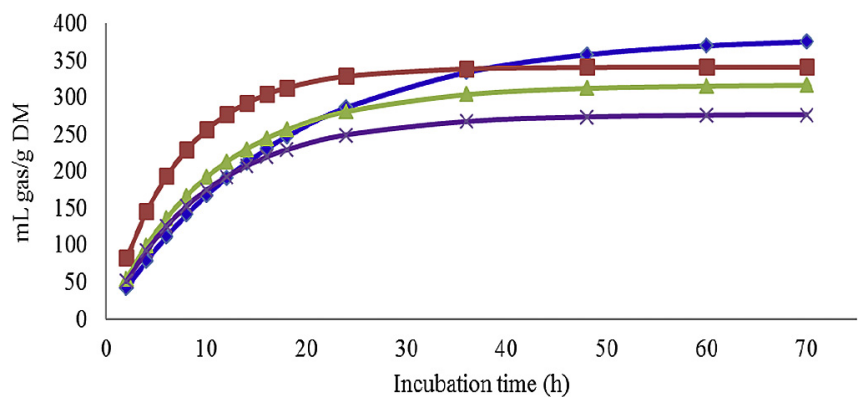

Fig. 2. In vitro rumen gas production ( $\mathrm{mL} / \mathrm{g}$ incubated $\mathrm{DM})$ of calf's diet supplemented with: no additive (control) (- -), xylanase (- - -), Saccharomyces cerevisiae (- $\left.\boldsymbol{\Delta}_{-}\right)$, and their mixture $\left(\mathbf{z}_{\mathbf{-}}\right)$ incubated with rumen inoculum from calves fed on diet supplemented with the same feed additives for $60 \mathrm{~d}$ of age.

and SC additives compared with the control.

Fig. 3 shows the in vitro rumen $\mathrm{CH}_{4}$ production $(\mathrm{mL} / \mathrm{g}$ incubated $\mathrm{DM}$ ) of a calf's diet supplemented with XYL, SC and XYL + SC mixture. Interactions between additive and rumen liquor were observed $(P<0.05)$ for asymptotic and rate of $\mathrm{CH}_{4}$ productions (Table 1$)$. Moreover, interactions were observed $(P<0.05)$ between additive and dose for asymptotic $\mathrm{CH}_{4}$, initial delay before $\mathrm{CH}_{4}$ production and at $48 \mathrm{~h}$ incubation for $\mathrm{mL} / \mathrm{g}$ incubated DM. Xylanase, $\mathrm{SC}$, and XYL + SC mixture in all doses except for $0 \mathrm{mg}$ dose of $\mathrm{XYL}+\mathrm{SC}$ mixture additive affected $(P<0.05) \mathrm{CH}_{4}$ production when compared with the control treatment. Also the mean productions of $\mathrm{CH}_{4}$ from the $\mathrm{XYL}, \mathrm{SC}$ and $\mathrm{XYL}+\mathrm{SC}$ mixture were decreased $(P<0.05)$ compared with the control. The lowest asymptotic $\mathrm{CH}_{4}$ production was observed at the high dose of XYL + SC mixture which was lower $(P<0.05)$ than that of the control treatment. No effect $(P>0.05)$ was observed in all the doses on the rate of $\mathrm{CH}_{4}$ production except at $3 \mu \mathrm{L} \mathrm{XYL/g} \mathrm{DM} \mathrm{that} \mathrm{was} \mathrm{increased}(P<0.05)$, compared with the control, with no observable effect $(P>0.05)$ being noticed with the addition of SC and XYL + SC mixture additives. Similarly, there was no statistically significant difference $(P>0.05)$ in the lag time of $\mathrm{CH}_{4}$ production at all doses when compared with the control treatment. The asymptotic $\mathrm{CH}_{4}$ production reduced for all the additives, while the rate of $\mathrm{CH}_{4}$ production was lowest for XYL + SC (9\%).

Fig. 4 shows the in vitro rumen $\mathrm{CO}_{2}$ production $(\mathrm{mL} / \mathrm{g}$ incubated $\mathrm{DM}$ ) of a calf's diet supplemented with XYL, SC and XYL + SC mixture. Interaction was observed $(P<0.05)$ between additive and dose for $\mathrm{mL} / \mathrm{g}$ incubated $\mathrm{DM}$ but there were no effects for $\mathrm{mL} / \mathrm{g}$ degraded DM and proportional $\mathrm{CO}_{2}$ production at 6,24 and $48 \mathrm{~h}$ incubation. The XYL + SC had the highest asymptotic $\mathrm{CO}_{2}(81 \%)$ followed by SC (37\%) and XYL (20\%). The mean asymptotic $\mathrm{CO}_{2}$ production was higher $(P<0.05)$ for SC and XYL + SC mixture additives addition than for the control (without additive). The highest asymptotic $\mathrm{CO}_{2}$ production was recorded for the treatment containing $2 \mathrm{mg} \mathrm{SC} / \mathrm{g}$ DM and high dose of XYL + SC mixture; it was greater in the two treatments $(P<0.05)$ than in the control but a decrease below the control was observed at $6 \mu \mathrm{L} \mathrm{XYL/g} \mathrm{DM} \mathrm{and}$ $0 \mathrm{mg} \mathrm{SC} / \mathrm{g}$ DM. The mean rate of GP differed $(P<0.05)$ only with the addition of XYL and not with $\mathrm{SC}$ and $\mathrm{XYL}+\mathrm{SC}$ mixture additives when compared with the control. All the values of the lag time of $\mathrm{CO}_{2}$ production ranged from the lowest scale of $8.2 \mathrm{~mL} / \mathrm{g} \mathrm{DM}$ in $2 \mathrm{mg}$ SC to the highest gauge of $10.9 \mathrm{~mL} / \mathrm{g}$ DM in the high dose of $\mathrm{XYL}+\mathrm{SC}$ mixture. There was no statistically significant effect $(P>0.05)$ on mean lag time of $\mathrm{CO}_{2}$ production for $\mathrm{XYL}$, SC additives and the control, but a statistically significant effect was observed for $\mathrm{XYL}+\mathrm{SC}$ mixture compared with the control treatment.

From previous studies, negligible amounts of $\mathrm{CH}_{4}$ were released during the first $6 \mathrm{~h}$ of fermentation. Because the production peak 
Table 1

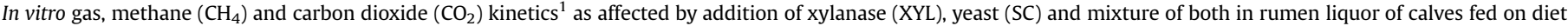
supplemented with xylanase and/or yeast for $60 \mathrm{~d}$ of age.

\begin{tabular}{|c|c|c|c|c|c|c|c|c|c|c|c|}
\hline \multirow[t]{2}{*}{ Rumen liquor from calves fed on: } & \multirow[t]{2}{*}{ Additive: } & \multirow[t]{2}{*}{ Dose (/g DM) } & \multicolumn{3}{|c|}{ Gas production $(\mathrm{mL} / \mathrm{g} \mathrm{DM})^{2}$} & \multicolumn{3}{|c|}{$\mathrm{CH}_{4}$ production $(\mathrm{mL} / \mathrm{g} \mathrm{DM})^{3}$} & \multicolumn{3}{|c|}{$\mathrm{CO}_{2}$ production $(\mathrm{mL} / \mathrm{g} \mathrm{DM})^{4}$} \\
\hline & & & $b$ & $c$ & Lag & $b$ & $c$ & Lag & $b$ & $c$ & Lag \\
\hline Control & No additive & 0 & $383^{\mathrm{Aa}}$ & $0.058^{\mathrm{Cc}}$ & $2.69^{\mathrm{Ce}}$ & $108^{\mathrm{Aa}}$ & $0.044^{\mathrm{Bbc}}$ & $7.15^{\mathrm{ab}}$ & $38^{\mathrm{Cde}}$ & $0.041 \mathrm{~B}^{\mathrm{c}}$ & $8.48 \mathrm{~B}^{\mathrm{c}}$ \\
\hline \multirow[t]{4}{*}{$\mathrm{XYL}$} & XYL & $0 \mu \mathrm{L}$ & $375^{\mathrm{a}}$ & $0.141^{\mathrm{a}}$ & $5.28^{\mathrm{abc}}$ & $67^{\mathrm{bc}}$ & $0.093^{\mathrm{ab}}$ & $8.93^{\mathrm{a}}$ & $58^{\mathrm{c}}$ & $0.147^{\mathrm{ab}}$ & $10.17^{\mathrm{ab}}$ \\
\hline & & $3 \mu \mathrm{L}$ & $348^{a}$ & $0.148^{\mathrm{a}}$ & $5.28^{\mathrm{abc}}$ & $60^{c}$ & $0.102^{\mathrm{a}}$ & $8.30^{\mathrm{ab}}$ & $50^{\mathrm{cd}}$ & $0.162^{\mathrm{a}}$ & $9.78^{\mathrm{abc}}$ \\
\hline & & $6 \mu \mathrm{L}$ & $303^{\mathrm{ab}}$ & $0.128^{\mathrm{ab}}$ & $5.43^{\mathrm{abc}}$ & $64^{c}$ & $0.070^{\mathrm{abc}}$ & $6.87^{\mathrm{ab}}$ & $35^{\mathrm{de}}$ & $0.060^{c}$ & $8.39^{c}$ \\
\hline & & Mean & $352^{\mathrm{AB}}$ & $0.119^{\mathrm{A}}$ & $4.67^{\mathrm{A}}$ & $75^{\mathrm{B}}$ & $0.077^{\mathrm{A}}$ & 7.81 & $45^{\mathrm{BC}}$ & $0.103^{\mathrm{A}}$ & $9.21^{\mathrm{AB}}$ \\
\hline \multirow[t]{4}{*}{ SC } & SC & $0 \mathrm{mg}$ & $331^{\mathrm{ab}}$ & $0.000^{\mathrm{bc}}$ & $6.59^{\mathrm{a}}$ & $63^{c}$ & $0.049^{\mathrm{bc}}$ & $8.53^{\mathrm{ab}}$ & $31^{\mathrm{e}}$ & $0.074^{\mathrm{c}}$ & $8.74^{\mathrm{bc}}$ \\
\hline & & $2 \mathrm{mg}$ & $329^{\mathrm{ab}}$ & $0.105^{\mathrm{abc}}$ & $5.58^{\mathrm{ab}}$ & $69^{\mathrm{bc}}$ & $0.062^{\mathrm{abc}}$ & $8.01^{\mathrm{ab}}$ & $90^{\mathrm{ab}}$ & $0.087^{\mathrm{bc}}$ & $8.18^{c}$ \\
\hline & & $4 \mathrm{mg}$ & $295^{\mathrm{ab}}$ & $0.108^{a b c}$ & $6.02^{\mathrm{a}}$ & $67^{\mathrm{bc}}$ & $0.050^{\mathrm{bc}}$ & $9.03^{\mathrm{a}}$ & $47^{\text {cde }}$ & $0.043^{c}$ & $8.50^{\mathrm{bc}}$ \\
\hline & & Mean & $334^{\mathrm{AB}}$ & $0.086^{\mathrm{BC}}$ & $5.22^{\mathrm{A}}$ & $77^{\mathrm{B}}$ & $0.051^{\mathrm{B}}$ & 8.18 & $51^{\mathrm{B}}$ & $0.061^{\mathrm{B}}$ & $8.48^{\mathrm{B}}$ \\
\hline \multirow[t]{4}{*}{$\mathrm{XYL}+\mathrm{SC}$} & $\mathrm{XYL}+\mathrm{SC}$ & 0 & $295^{\mathrm{ab}}$ & $0.100^{\mathrm{abc}}$ & $3.78^{\mathrm{de}}$ & $105^{\mathrm{ab}}$ & $0.042^{c}$ & $7.30^{\mathrm{ab}}$ & $97^{\mathrm{a}}$ & $0.041^{\mathrm{c}}$ & $10.49^{\mathrm{a}}$ \\
\hline & & $3 \mu \mathrm{L} \mathrm{XYL}+2 \mathrm{mg} \mathrm{SC}$ & $297^{\mathrm{ab}}$ & $0.105^{\mathrm{abc}}$ & $4.07^{\text {cde }}$ & $74^{\mathrm{abc}}$ & $0.050^{\mathrm{bc}}$ & $6.40^{\mathrm{b}}$ & $58^{\mathrm{c}}$ & $0.064^{\mathrm{c}}$ & $9.54^{\mathrm{abc}}$ \\
\hline & & $6 \mu \mathrm{L} \mathrm{XYL}+4 \mathrm{mg} \mathrm{SC}$ & $240^{\mathrm{b}}$ & $0.111^{\mathrm{abc}}$ & $4.37^{\mathrm{bcd}}$ & $55^{c}$ & $0.055^{\mathrm{abc}}$ & $7.73^{\mathrm{ab}}$ & $80^{\mathrm{b}}$ & $0.049^{c}$ & $10.88^{\mathrm{a}}$ \\
\hline & & Mean & $304^{\mathrm{B}}$ & $0.094^{\mathrm{AB}}$ & $3.73^{\mathrm{B}}$ & $86^{\mathrm{B}}$ & $0.048^{\mathrm{B}}$ & 7.15 & $68^{\mathrm{A}}$ & $0.049^{\mathrm{B}}$ & $9.85^{\mathrm{A}}$ \\
\hline \multicolumn{12}{|c|}{ Additive effectiveness (as $\%$ of no additive treatment) ${ }^{5}$ : } \\
\hline & & $\mathrm{XYL}$ & -8 & 105 & 74 & -31 & 75 & 9 & 20 & 151 & 9 \\
\hline & & SC & -13 & 49 & 94 & -29 & 16 & 14 & 37 & 49 & 0 \\
\hline & & $\mathrm{XYL}+\mathrm{SC}$ & -21 & 62 & 39 & -21 & 9 & 0 & 81 & 20 & 16 \\
\hline SEM $^{6}$ & & & 20.6 & 0.0119 & 0.291 & 7.5 & 0.0091 & 0.434 & 3.2 & 0.0140 & 0.327 \\
\hline \multicolumn{12}{|l|}{$P$ value } \\
\hline Additive type & & & 0.138 & 0.033 & $<0.001$ & 0.306 & 0.022 & 0.579 & $<0.001$ & 0.008 & 0.008 \\
\hline Rumen liquor type & & & 0.007 & $<0.001$ & $<0.001$ & $<0.001$ & 0.038 & 0.004 & $<0.001$ & 0.001 & $<0.001$ \\
\hline Additive dose & & & 0.031 & 0.255 & 0.133 & 0.024 & 0.551 & 0.159 & $<0.001$ & 0.002 & 0.154 \\
\hline Additive type $\times$ Rumen liquor typ & & & 0.175 & 0.027 & $<0.001$ & 0.017 & 0.025 & 0.168 & $<0.001$ & 0.003 & 0.030 \\
\hline Additive type $\times$ additive dose & & & 0.798 & 0.468 & 0.754 & 0.015 & 0.109 & 0.007 & $<0.001$ & 0.004 & 0.001 \\
\hline
\end{tabular}

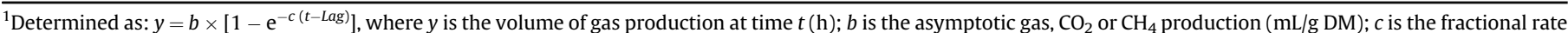
of fermentation (per h), and $\mathrm{Lag}(\mathrm{h})$ is the discrete lag time prior to any gas, $\mathrm{CO}_{2}$ or $\mathrm{CH}_{4}$ formation.

${ }^{2} b$ is the asymptotic gas production ( $\left.\mathrm{mL} / \mathrm{g} \mathrm{DM}\right) ; c$ is the rate of gas production (per h); Lag is the initial delay before gas formation (h).

${ }^{3} b$ is the asymptotic methane production ( $\mathrm{mL} / \mathrm{g} \mathrm{DM}$ ); $c$ is the rate of methane production (per h); Lag is the initial delay before methane formation (h).

${ }^{4} b$ is the asymptotic carbon dioxide production ( $\left.\mathrm{mL} / \mathrm{g} \mathrm{DM}\right) ; c$ is the rate of carbon dioxide production (per h); Lag is the initial delay before carbon dioxide formation (h).

${ }^{5}$ Based on the mean value of each feed additive at different doses.

${ }^{6} \mathrm{SEM}$, standard error of the mean.

$(A, B, C)$ arithmetic mean in the same column with different letters differ $(P<0.05)$ among additives (the mean of all doses for each additive)

(a,b,c,d,e) arithmetic mean in the same row with different letters differ $(P<0.05)$ among doses of different feed additives.

occurred approximately at $24 \mathrm{~h}$ of fermentation, and then started to decrease until $48 \mathrm{~h}$ of incubation, after which negligible amounts were still released, only productions at 6,24 , and $48 \mathrm{~h}$ of incubation were tabulated, while productions at other times of incubation were presented as figures. Table 2 shows the in vitro $\mathrm{CH}_{4}$ and $\mathrm{CO}_{2}$ productions at 6,24 and $48 \mathrm{~h}$ after incubation as affected by the addition of XYL, SC and a mixture of both in rumen liquor of calves fed on diet supplemented with the same three additives for $60 \mathrm{~d}$ of age. At 6,24 and $48 \mathrm{~h}$ of incubation, XYL, SC and XYL + SC mixture did affect $\mathrm{CH}_{4}$ production ( $\mathrm{mL} / \mathrm{g}$ incubated DM) compared with the control treatment. However, the mixture of XYL and SC had no effect on the $\mathrm{CH}_{4}$ production at 24 and $48 \mathrm{~h}$ compared with their respective controls. Moreover, $\mathrm{CH}_{4}$ production $(\mathrm{mL} / \mathrm{g}$ degraded $\mathrm{DM}$ ) was decreased at the high dose of XYL + SC mixture at 24 and $48 \mathrm{~h}$ of incubation. There was an observable reduction in the $\mathrm{CH}_{4}$ production ( $\mathrm{mL} / \mathrm{g}$ degraded $\mathrm{DM}$ ) in XYL, SC and mixture of XYL $+\mathrm{SC}$ mixture compared with the control. The proportional $\mathrm{CH}_{4}$ production at 6, 24 and $48 \mathrm{~h}$ of incubation was reduced slightly but the reduction was marginal $(P>0.05)$ compared with the control treatment, while addition of additives resulted in a decreased proportional $\mathrm{CH}_{4}$ production. On the other hand, addition of XYL, $\mathrm{SC}$ and XYL $+\mathrm{SC}$ mixture increased $(P<0.05)$ the production of $\mathrm{CO}_{2}$ $(\mathrm{mL} / \mathrm{g}$ incubated $\mathrm{DM})$ and $\mathrm{mL} / \mathrm{g}$ degraded $\mathrm{DM}$ but had no effect $(P>0.05)$ on the proportional $\mathrm{CO}_{2}$ production when compared with the control treatment.

\section{Discussion}

Agricultural wastes are important sources of global GHG emissions which are estimated to rise to about 8.2 billion $t$ of $\mathrm{CO}_{2}$ equivalents by 2030 , if adequate mitigation technique is not properly implemented (Slade et al., 2016). Apart from the impacts of GHG, enteric $\mathrm{CH}_{4}$ emission contributes to a loss of net feed energy that cannot be used in ruminant animals for production purposes (Johnson and Johnson, 1995). Because of these challenges, intensive research efforts are recently directed towards ruminant animals $\mathrm{CH}_{4}$ mitigation (Elghandour et al., 2016b). The use of in vitro GP technique is a powerful, simple and sensitive screening method for evaluating substrate fermentation or degradation and for monitoring the efficacy of feed additives (Elghandour et al., 2015) and GHG production (Elghandour et al., 2016c). The interactions between additive type and rumen liquor, as well as additive and additive dose, for some measured parameters, suggest that both fermentation kinetics and gas production are rumen liquor and additive-dose dependent, underpinning the importance of identifying optimal supplemental levels of each additive for each rumen liquor type. The addition of enzyme at all doses had no effects on the asymptotic GP. This finding is in agreement with the results of Jalilvand et al. (2008) who observed that the addition of enzyme additives to forage had negligible effects on GP kinetics, and opined that the effects of enzyme addition depend on the fiber content, structural polysaccharide compositions of the substrate and difference in enzyme composition. There were interactions between additive and rumen liquor for rate of GP and initial delay before GP. Enzyme addition significantly affected the rate of GP, which contradicts previous reports on other enzyme preparations and types (Jalilvand et al., 2008). Recent studies including in vivo (Morsy et al., 2016) and in vitro (Elghandour et al., 2016a) experiments showed that supplementation of ruminant diets with exogenous enzymes could improve feed utilization, digestion of 


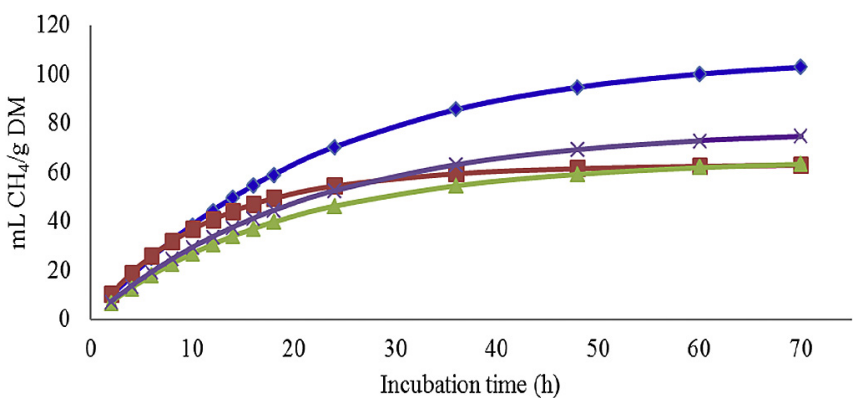

Fig. 3. In vitro rumen methane $\left(\mathrm{CH}_{4}\right)$ production $(\mathrm{mL} / \mathrm{g}$ incubated $\mathrm{DM})$ of calf's diet supplemented with: no additive (control) (- -), xylanase (- $\mathbf{-}-)$, Saccharomyces cerevisiae (- $\left.\Lambda_{-}\right)$, and their mixture (_- $\left.\times_{-}\right)$incubated with rumen inoculum from calves fed on diet supplemented with the same feed additives for $60 \mathrm{~d}$ of age.

$\mathrm{DM}$, and animal performance by improving DM degradation (Alsersy et al., 2015).

Ahmed et al. (2015) showed that the supplementation of SC to diets of ruminants improved feed utilization. In contrast, Corona et al. (1999) reported that supplementation of SC to cow diets did not affect digestibility of DM, hemicellulose and starch. Yeast additives had no effect on rate of GP but there was a slight increase in rate of GP compared with the control. This result is in contrast to the work of Rodriguez et al. (2015) who reported a decreased rate of GP in response to SC additives. The differences in results may be due to the composition and incubation of the substrates (Elghandour et al., 2014).

Xylanase, SC and their mixture at all doses, except that of $0 \mathrm{mg}$ dose of $\mathrm{XYL}+\mathrm{SC}$ mixture, decreased $\mathrm{CH}_{4}$ production when compared to the control treatment. This pronounced decrease in $\mathrm{CH}_{4}$ production suggests that the use of $\mathrm{XYL}$, SC or its mixture as additives in ruminant diets may serve as efficient methods to reduce $\mathrm{CH}_{4}$ emission from ruminant production. Several researches have reported a reduction of $\mathrm{CH}_{4}$ production with SC supplementation. For instance $58 \%$ reduction in $\mathrm{CH}_{4}$ production have been reported by Newbold and Rode (2006) with the addition of SC in ruminant diets. Besides, Polyorach et al. (2014) noted a decrease in in vitro $\mathrm{CH}_{4}$ production with supplementation of $\mathrm{SC}$, which supports our findings.

Of the several studies which have evaluated the effects of exogenous enzymes on $\mathrm{CH}_{4}$ emission in the rumen, few reported an absolute increase in production of $\mathrm{CH}_{4}$ with addition of exogenous enzymes supplementation to the ruminant diets (Beauchemin et al., 2009). Dong et al. (1999) reported 43\% increase in $\mathrm{CH}_{4}$ production when cellulase and XYL were used as supplements with hay in RUSITEC system. Colombatto et al. (2003) reported that there was no effect of enzymes supplement on $\mathrm{CH}_{4}$ production in continuous culture system. McGinn et al. (2004) observed no effect on $\mathrm{CH}_{4}$ production in steers fed with barley silage-based diets supplemented with different feed additives including exogenous enzymes. In contrast, Kholif et al. (2016) reported that the addition of enzymes at certain doses reduced $\mathrm{CH}_{4}$ production in equine diets. Salem et al. (2015b) observed the same results in horses fed diet supplemented with exogenous enzymes. In the present study, addition of enzymes at all doses decreased $\mathrm{CH}_{4}$ production. This may be due to the possible stimulation of reductive acetogens in the rumen that alters hydrogen $\left(\mathrm{H}_{2}\right)$ metabolism and its utilization by methanogens in a manner that reduces $\mathrm{CH}_{4}$ formation and emissions (Stewart et al., 1997). The reduction in $\mathrm{CH}_{4}$ production by the addition of a combination of XYL and SC at high dose depicts a positive impact on rumen fermentation, although the observed pronounced decrease in $\mathrm{CH}_{4}$ production at high dose of the added additive was accompanied by a slight decrease in asymptotic GP,

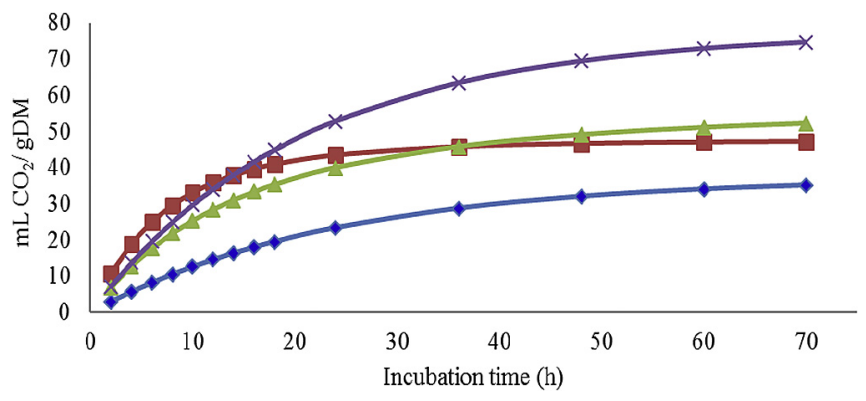

Fig. 4. In vitro rumen carbon dioxide $\left(\mathrm{CO}_{2}\right)$ production $(\mathrm{mL} / \mathrm{g}$ incubated $\mathrm{DM})$ of a calfs diet supplemented with: no additive (control) (- -), xylanase (- $\mathbf{-}-)$, Saccharomyces cerevisiae (- $\left.\Delta_{-}\right)$, and their mixture $\left({ }_{-} X_{-}\right)$incubated with rumen inoculum from calves fed on diet supplemented with the same feed additives for $60 \mathrm{~d}$ of age.

indicating a direct inhibitory effect of rumen fermentation kinetics.

Many gases consisting of mainly $\mathrm{CH}_{4}, \mathrm{CO}_{2}$ and $\mathrm{H}_{2}$ are produced during ruminal fermentation process within the rumen. In this study, addition of additives at all doses slightly increased $\mathrm{CO}_{2}$ production at 6,24 and $48 \mathrm{~h}$ of incubation. At $6 \mathrm{~h}$ of incubation, there was no $\mathrm{CO}_{2}$ production in all the additives as well as in the control. Decreased $\mathrm{CO}_{2}$ production below the control treatment was observed at $6 \mu \mathrm{L} \mathrm{XYL/g} \mathrm{DM} \mathrm{and} 0 \mathrm{mg} \mathrm{SC} / \mathrm{g}$ DM. This reduction in $\mathrm{CO}_{2}$ production and decrease in rate of $\mathrm{CO}_{2}$ may be due to increased cell wall content that can reduce the microbial activities. Elghandour et al. (2016c) reported a decreased $\mathrm{CO}_{2}$ production when corn grain was replaced with soybean hulls. Elghandour et al. (2016d) observed that replacement of corn grain with prickly pear cactus increased $\mathrm{CO}_{2}$ production. However, both experiments used the same organic acid addition, indicating that the observed different effect may be ration dependent. To the best of our knowledge, there is little information on the effects of supplementing diets of ruminants with enzymes and SC additives on $\mathrm{CO}_{2}$ production which makes it difficult to compare the present results with previous results. The asymptotic $\mathrm{CO}_{2}$ production recorded the highest values for $2 \mathrm{mg} \mathrm{SC} / \mathrm{g} \mathrm{DM}(90 \mathrm{~mL} / \mathrm{g} \mathrm{DM})$ and $(97$ and $80 \mathrm{~mL} / \mathrm{g}$ $\mathrm{DM}$ ) for 0 and high dose of XYL + SC mixture; the three treatments had greater productions than the control treatment ( $38 \mathrm{~mL} / \mathrm{g} \mathrm{DM}$ ). In this study, inclusion of additives had an increasing effect on asymptotic $\mathrm{CO}_{2}$ production.

\section{Conclusions}

Methane and $\mathrm{CO}_{2}$ from enteric fermentation in the digestive system of ruminants are two major contributors of greenhouse gas emissions in the world. Mitigating the loss of these gases from ruminant production will not only reduce greenhouse gas production from agricultural wastes but also will decrease loss of net feed energy to the animal. This study demonstrated that supplementing ruminant's diets with xylanase, $S$. cerevisiae and their mixture at different doses for $60 \mathrm{~d}$ of age changed the pattern of ruminal production of gas, $\mathrm{CH}_{4}$ and $\mathrm{CO}_{2}$. Addition of a mixture of xylanase and $S$. cerevisiae at a high dose significantly reduced asymptotic gas production compared with other treatments with dose-dependent results. Inclusion of xylanase, S. cerevisiae and their mixture reduced asymptotic gas production to $<1 \%$. Again, addition of additives in the diets of ruminants at all doses had statistically significant reduction effect on $\mathrm{CH}_{4}$ production. The pronounced decrease in $\mathrm{CH}_{4}$ production shows that the use of xylanase, $S$. cerevisiae or their mixture as additives in ruminant diets may serve as efficient method to reduce $\mathrm{CH}_{4}$ emission from ruminant production. This study also established that the mixture of xylanase and $S$. cerevisiae was more efficient and promising in 
Table 2

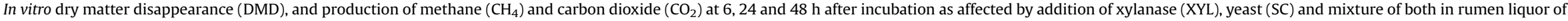
calves fed on diet supplemented with xylanase and/or yeast for $60 \mathrm{~d}$ of age.

\begin{tabular}{|c|c|c|c|c|c|c|c|c|c|c|c|c|c|c|c|c|c|c|c|c|c|}
\hline \multirow{3}{*}{$\begin{array}{l}\text { Rumen liquor } \\
\text { from calves fed on: }\end{array}$} & \multirow[t]{3}{*}{ Additive: } & \multirow{3}{*}{$\begin{array}{l}\text { Dose } \\
\text { (mg/g DM) }\end{array}$} & \multirow[t]{3}{*}{ DMD } & \multicolumn{9}{|c|}{$\mathrm{CH}_{4}$ production } & \multicolumn{9}{|c|}{$\mathrm{CO}_{2}$ production } \\
\hline & & & & \multicolumn{3}{|c|}{$\mathrm{mL} / \mathrm{g}$ incubated DM } & \multicolumn{3}{|c|}{$\mathrm{mL} / \mathrm{g}$ degraded $\mathrm{DM}$} & \multicolumn{3}{|c|}{ Proportional $\mathrm{CH}_{4}$ production } & \multicolumn{3}{|c|}{$\mathrm{mL} / \mathrm{g}$ incubated $\mathrm{DM}$} & \multicolumn{3}{|c|}{$\underline{\mathrm{mL} / \mathrm{g} \text { degraded } \mathrm{DM}}$} & \multicolumn{3}{|c|}{ Proportional $\mathrm{CO}_{2}$ production } \\
\hline & & & & $6 \mathrm{~h}$ & $24 \mathrm{~h}$ & $48 \mathrm{~h}$ & $6 \mathrm{~h}$ & $24 \mathrm{~h}$ & $48 \mathrm{~h}$ & $6 \mathrm{~h}$ & $24 \mathrm{~h}$ & $48 \mathrm{~h}$ & $6 \mathrm{~h}$ & $24 \mathrm{~h}$ & $48 \mathrm{~h}$ & $6 \mathrm{~h}$ & $24 \mathrm{~h}$ & $48 \mathrm{~h}$ & $6 \mathrm{~h}$ & $24 \mathrm{~h}$ & $48 \mathrm{~h}$ \\
\hline Control & No additive & 0 & 693 & 25 & $70.2^{\mathrm{Aa}}$ & $94.7^{\mathrm{Aa}}$ & 2.47 & 85 & $128^{\mathrm{Aa}}$ & $1.53^{\mathrm{Aa}}$ & $21^{\mathrm{A}}$ & $25^{\mathrm{A}}$ & $8^{\mathrm{Bb}}$ & $24^{\mathrm{Bd}}$ & $32^{\mathrm{Ce}}$ & 0 & 34 & 65 & 0 & 8 & 13 \\
\hline \multirow[t]{4}{*}{ XYL } & XYL & $0 \mu \mathrm{L}$ & 656 & 29 & $60^{\mathrm{ab}}$ & $66^{\mathrm{abc}}$ & 2.56 & 72 & $82^{\mathrm{ab}}$ & $0.79^{\mathrm{ab}}$ & 13 & 15 & $34^{\mathrm{a}}$ & $56^{\mathrm{ab}}$ & $58^{\mathrm{bc}}$ & 0 & 64 & 70 & 0 & 12 & 12 \\
\hline & & $3 \mu \mathrm{L}$ & 644 & 28 & $55^{\mathrm{ab}}$ & $60^{\mathrm{bc}}$ & 2.22 & 78 & $91^{\mathrm{ab}}$ & $0.70^{\mathrm{ab}}$ & 15 & 17 & $31^{\mathrm{a}}$ & $49^{\mathrm{abc}}$ & $50^{\mathrm{cd}}$ & 0 & 72 & 78 & 0 & 14 & 14 \\
\hline & & $6 \mu \mathrm{L}$ & 642 & 22 & $49^{\mathrm{ab}}$ & $59^{c}$ & 2.59 & 63 & $81^{\mathrm{ab}}$ & $1.00^{\mathrm{ab}}$ & 14 & 17 & $11^{\mathrm{b}}$ & $26^{\mathrm{d}}$ & $33^{e}$ & 0 & 53 & 68 & 0 & 12 & 14 \\
\hline & & Mean & 659 & 26 & $59^{\mathrm{AB}}$ & $70^{\mathrm{B}}$ & 2.46 & 75 & $96^{\mathrm{B}}$ & $1.00^{\mathrm{B}}$ & $16^{\mathrm{AB}}$ & $19^{\mathrm{B}}$ & $21^{\mathrm{A}}$ & $39^{A}$ & $43^{B}$ & 0 & 56 & 70 & 0 & 11 & 13 \\
\hline \multirow[t]{4}{*}{$\mathrm{SC}$} & SC & $0 \mathrm{mg}$ & 665 & 16 & $43^{\mathrm{b}}$ & $56^{c}$ & 0.85 & 53 & $79^{\mathrm{ab}}$ & $0.51^{\mathrm{b}}$ & 13 & 16 & $11^{\mathrm{b}}$ & $25^{\mathrm{d}}$ & $30^{\mathrm{e}}$ & 0 & 37 & 51 & 0 & 9 & 11 \\
\hline & & $2 \mathrm{mg}$ & 671 & 22 & $54^{\mathrm{ab}}$ & $66^{\mathrm{abc}}$ & 1.41 & 60 & $90^{\mathrm{ab}}$ & $0.62^{\mathrm{b}}$ & 14 & 19 & $31 .^{\mathrm{a}}$ & $65^{\mathrm{a}}$ & $77^{\mathrm{a}}$ & 0 & 115 & 137 & 0 & 25 & 28 \\
\hline & & $4 \mathrm{mg}$ & 625 & 16 & $42^{\mathrm{b}}$ & $56^{c}$ & 1.42 & 59 & $84^{\mathrm{ab}}$ & $0.58^{\mathrm{b}}$ & 13 & 17 & $11^{\mathrm{b}}$ & $30^{\mathrm{cd}}$ & $41^{\mathrm{de}}$ & 0 & 64 & 81 & 0 & 13 & 15 \\
\hline & & Mean & 664 & 20 & $52^{\mathrm{B}}$ & $68^{\mathrm{B}}$ & 1.54 & 64 & $95^{\mathrm{B}}$ & $0.81^{\mathrm{B}}$ & $15^{\mathrm{B}}$ & $19^{\mathrm{B}}$ & $15^{\mathrm{AB}}$ & $36^{A}$ & $45^{\mathrm{B}}$ & 0 & 63 & 83 & 0 & 14 & 17 \\
\hline \multirow[t]{4}{*}{$\mathrm{XYL}+\mathrm{SC}$} & $\mathrm{XYL}+\mathrm{SC}$ & 0 & 681 & 23 & $67^{\mathrm{ab}}$ & $91^{\mathrm{ab}}$ & 2.48 & 77 & $102^{\mathrm{ab}}$ & $1.28^{\mathrm{ab}}$ & 20 & 24 & $21^{\mathrm{ab}}$ & $60^{\mathrm{ab}}$ & $83^{a}$ & 0 & 52 & 74 & 0 & 13 & 16 \\
\hline & & $\begin{array}{l}3 \mu \mathrm{LXYL} \\
+2 \mathrm{mg} \mathrm{SC}\end{array}$ & 674 & 19 & 50 & $66^{\mathrm{abc}}$ & 2.20 & 58 & $77^{\mathrm{ab}}$ & $1.09^{\mathrm{ab}}$ & 15 & 18 & $18^{\mathrm{ab}}$ & $44^{\mathrm{bcd}}$ & $54^{\text {cd }}$ & 0 & 39 & 49 & 0 & 10 & 12 \\
\hline & & $\begin{array}{l}6 \mu \mathrm{L} \mathrm{XYL} \\
+4 \mathrm{mg} \mathrm{SC}\end{array}$ & 678 & 16 & $40^{\mathrm{b}}$ & $51^{\mathrm{c}}$ & 1.80 & 53 & $68^{\mathrm{b}}$ & $1.13^{\mathrm{ab}}$ & 17 & 19 & $20^{\mathrm{ab}}$ & $55^{\mathrm{ab}}$ & $72^{\mathrm{ab}}$ & 0 & 50 & 68 & 0 & 15 & 19 \\
\hline & & Mean & 681 & 21 & $57^{\mathrm{AB}}$ & $76^{\mathrm{B}}$ & 2.24 & 68 & $94^{\mathrm{B}}$ & $1.26^{\mathrm{AB}}$ & $18^{\mathrm{AB}}$ & $21^{\mathrm{AB}}$ & $17^{\mathrm{AB}}$ & $46^{\mathrm{A}}$ & $60^{A}$ & 0 & 44 & 64 & 0 & 12 & 15 \\
\hline \multicolumn{22}{|c|}{ Additive effectiveness (as \% of no additive treatment) ${ }^{1}$} \\
\hline & XYL & & -5 & 2.8 & -17 & -26 & -0.4 & -12 & -25 & -35 & -24 & -26 & 154 & 64 & 34.27 & 0 & 63 & 8. & 0 & 36 & 6 \\
\hline & SC & & -4 & -21 & -25 & -28 & -38 & -24 & -26 & -47 & -28 & -22 & 88 & 53 & 40 & 0 & 83 & 29 & 0 & 67 & 31 \\
\hline & $\mathrm{XYL}+\mathrm{SC}$ & & -2 & -17 & -19 & -20 & -9 & -20 & -27 & -18 & -13 & -14 & 105 & 94 & 88 & 0 & 28 & -0.8 & 0 & 39 & 17 \\
\hline \multicolumn{21}{|l|}{$P$ value } & 4.3 \\
\hline Additive type & & & 0.433 & 0.065 & 0.170 & 0.219 & 0.128 & 0.439 & 0.784 & 0.208 & 0.607 & 0.632 & 0.054 & $<0.001$ & $<0.001$ & 1.000 & 0.775 & 0.937 & 1.000 & 0.962 & 0.962 \\
\hline Rumen liquor type & & & 0.040 & 0.347 & 0.004 & $<0.001$ & 0.134 & 0.032 & $<0.001$ & $<0.001$ & 0.003 & 0.001 & $<0.001$ & $<0.001$ & $<0.001$ & 1.000 & 0.257 & 0.983 & 1.000 & 0.330 & 0.926 \\
\hline Additive dose & & & 0.422 & 0.083 & 0.013 & 0.008 & 0.712 & 0.496 & 0.476 & 0.872 & 0.936 & 0.840 & $<0.001$ & $<0.001$ & $<0.001$ & 1.000 & 0.062 & 0.178 & 1.000 & 0.031 & 0.092 \\
\hline \multirow{2}{*}{\multicolumn{3}{|c|}{$\begin{array}{l}\text { Additive type } \times \text { Rumen liquor type } \\
\text { Additive } \times \text { additive dose }\end{array}$}} & 0.431 & 0.111 & 0.090 & 0.025 & 0.076 & 0.434 & 0.499 & 0.107 & 0.158 & 0.081 & 0.008 & $<0.001$ & $<0.001$ & 1.000 & 0.749 & 0.876 & 1.000 & 0.859 & 0.822 \\
\hline & & & 0.228 & 0.835 & 0.361 & 0.048 & 0.575 & 0.443 & 0.202 & 0.566 & 0.245 & 0.121 & 0.003 & 0.001 & $<0.001$ & 1.000 & 0.694 & 0.753 & 1.000 & 0.589 & 0.661 \\
\hline
\end{tabular}

${ }^{1}$ Based on the mean value of each feed additive at different doses.

${ }^{2} \mathrm{SEM}$, standard error of the mean.

$(A, B, C)$ arithmetic mean in the same column with different letters differ $(P<0.05)$ among additives (the mean of all doses for each additive).

(a,b,c,d,e) arithmetic mean in the same row with different letters differ $(\mathrm{P}<0.05)$ among doses of different feed additives. 
reducing gas and methane emissions arising from ruminant production. If this mitigation practice is adopted, it can serve as an environmental friendly way of feeding livestock leading to cleaner environmental production conditions in calf farming.

\section{Conflict of interest}

All authors declare that there are no present or potential conflicts of interest among the authors and other people or organizations that could inappropriately bias their work.

\section{Acknowledgements}

The authors acknowledge the financial support from the IAEA, Vienna, Austria (Research Contract Number MEX16307 within the D3.10.27 Coordinated Research Project). Kholif, A.E. thanks the National Council for Science and Technology (CONACyT, Mexico) and The World Academy of Sciences (TWAS, Italy) for supporting his postdoctoral fellowship at the Facultad de Medicina Veterinaria y Zootecnia, Universidad Autónoma del Estado de México.

\section{References}

Ahmed, M.H., Elghandour, M.M.Y., Salem, A.Z.M., Zeweil, H.S., Kholif, A.E., Klieve, A.V., Abdelrassol, A.M.A., 2015. Influence of Trichoderma reesei or Saccharomyces cerevisiae on performance, ruminal fermentation, carcass characteristics and blood biochemistry of lambs fed Atriplex nummularia and Acacia saligna mixture. Livest. Sci. 180, 90-97.

Alsersy, H., Salem, A.Z., Borhami, B.E., Olivares, J., Gado, H.M., Mariezcurrena, M.D. Yacuot, M.H., Kholif, A.E., El-Adawy, M., Hernandez, S.R., 2015. Effect of Mediterranean saltbush (Atriplex halimus) ensilaging with two developed enzyme cocktails on feed intake, nutrient digestibility and ruminal fermentation in sheep. Anim. Sci. J. 86, 51-58.

AOAC, 1997. Official Methods of Analysis, sixteenth ed. Association of Official Analytical Chemists, Arlington, VA, USA.

Beauchemin, K.A., McAllister, T.A., McGinn, S.M., 2009. Dietary mitigation of enteric methane from cattle. In: CAB Reviews: Perspectives in Agriculture, Veterinary Science, Nutrition and Natural Resources. Vol. 4, (No. 035). CABI, Wallingford, UK, pp. 1-18.

Beauchemin, K.A., Colombatto, D., Morgavi, D.P., Yang, W.Z., 2003. Use of exogenous fibrolytic enzymes to improve feed utilization by ruminants. J. Anim. Sci. 81, E37-E47.

Colombatto, D., Hervás, G., Yang, W.Z., Beauchemin, K.A., 2003. Effects of enzyme supplementation of a total mixed ration on microbial fermentation in continuous culture, maintained at high and low pH. J. Anim. Sci. 81, 2617-2627.

Corona, L., Mendoza, G.D., Castrejón, F.A., Crosby, M.M., Cobos, M.A., 1999. Evaluation of two yeast cultures (Saccharomyces cerevisiae) on ruminal fermentation and digestion in sheep fed a corn stover diet. Small Rumin. Res. 31, 209-214.

Dick, M., Abreu Da Silva, M., Dewes, H., 2015. Mitigation of environmental impacts of beef cattle production in southern Brazil - evaluation using farm-based life cycle assessment. J. Clean. Prod. 87, 58-67.

Dong, Y., Bae, H.D., McAllister, T.A., Mathison, G.W., Cheng, K.J., 1999. Effects of exogenous fibrolytic enzymes, $\alpha$-bromoethanesulfonate and monensin on fermentation in a rumen simulation (Rusitec) system. Can. J. Anim. Sci. 79, 491-498.

Eckard, R.J., Grainger, C., De Klein, C.A.M., 2010. Options for the abatement of methane and nitrous oxide from ruminant production. Livest. Sci. 130, 47-56.

Elghandour, M.M.Y., Kholif, A.E., Hernández, J., Mariezcurrena, M.D., López, S., Camacho, L.M., Márquez, O., Salem, A.Z.M., 2016a. Influence of the addition of exogenous xylanase with or without pre-incubation on the in vitro ruminal fermentation of three fibrous feeds. Czech J. Anim. Sci. 61, 262-272.

Elghandour, M.M.Y., Kholif, A.E., López, S., German, D., Mendoza, G.D., Odongo, N.E., Salem, A.Z.M., 2016c. In vitro gas, methane, and carbon dioxide productions of high fibrous diet incubated with fecal inocula from horses in response to the supplementation with different live yeast additives. J. Equine Vet. Sci. 38, 64-71.

Elghandour, M.M.Y., Kholif, A.E., Marquez-Molina, O., Vazquez-Armijo, J.F., Puniya, A.K., Salem, A.Z.M., 2015. Influence of individual or mixed cellulose and xylanase mixture on in vitro rumen gas production kinetics of total mixed rations with different maize silage and concentrate ratios. Turk. J. Vet. Anim. Sci. 39,435 e 442.

Elghandour, M.M.Y, Kholif, A.E. Salem, A.Z.M. de Oca, R.M. Barbabosa, A. Mariezcurrena, M., Olafadehan, O.A., 2016b. Addressing sustainable ruminal methane and carbon dioxide emissions of soybean hulls by organic acid salts. J. Clean. Prod. 135, 194-200.

Elghandour, M.M.Y., Kholif, A.E., Salem, A.Z.M., Olafadehan, O.A., Kholif, A.M., 2016d Sustainable anaerobic rumen methane and carbon dioxide productions from prickly pear cactus flour by organic acid salts addition. J. Clean. Prod. 139,
1362-1369.

Elghandour, M.M.Y., Vázquez-Chagoyán, J.C., Salem, A.Z.M., Kholif, A.E., MartínezCastañeda, J.S., Camacho, L.M., Cerrillo-Soto, M.A., 2014. Effects of Saccharomyces cerevisiae at direct addition or pre-incubation on in vitro gas production kinetics and degradability of four fibrous feeds. Ital. J. Anim. Sci. 13, 295-301.

FAO, 2006. Livestock's Long Shadow, Environmental Issues and Options, Rome, Italy. FAO, 2016. Climate Is Changing. Food and Agriculture Must Change Too, Rome, Italy. France, J., Dijkstra, J., Dhanoa, M.S., López, S., Bannink, A., 2000. Estimating the extent of degradation of ruminant feeds from a description of their gas production profiles observed in vitro: derivation of models and other mathematical considerations. Br. J. Nutr. 83, 143-150.

Goering, M.K., Van Soest, P.J., 1970. Forage Fibre Analysis (Apparatus, Reagents, Procedures and Some Applications). Agriculture Handbook No. 379. Agricultural Research Service, USDA, Washington, USA.

Hassan, A.A., Salem, A.Z.M., Kholif, A.E., Samir, M., Yacout, M.H., Abu Hafsa, S.H., Mendoza, G.D., Elghandour, M.M.Y., Ayala, M., Lopez, S., 2016. Performance of crossbred dairy Friesian calves fed two levels of Saccharomyces cerevisiae: intake, digestion, ruminal fermentation, blood parameters and faecal pathogenic bacteria. J. Agric. Sci. 154, 1488-1498.

Hernandez, A., Kholif, A.E., Lugo-Coyote, R., Elghandour, M.M.Y., Cipriano, M., Rodríguez, G.B., Odongo, N.E., Salem, A.Z.M., 2017. The effect of garlic oil xylanase enzyme and yeast on biomethane and carbon dioxide production from 60-d old Holstein dairy calves fed a high concentrate diet. J. Clean. Prod. 142 2384-2392.

Hristov, A.N., Oh, J., Giallongo, F., Frederick, T.W., Harper, M.T., Weeks, H.L. Branco, A.F., Moate, P.J., Deighton, M.H., Williams, S.R.O., Kindermann, M. Duval, S., 2015. An inhibitor persistently decreased enteric methane emission from dairy cows with no negative effect on milk production. Proc. Nat. Acad. Sci. U. S. A. 112, 10663-10668.

Jalilvand, G. Odongo, N.E., López, S., Naserian, A., Valizadeh, R., Eftekhar Shahrodi, F., Kebreab, E., France, J., 2008. Effects of different levels of an enzyme mixture on in vitro gas production parameters of contrasting forages. Anim. Feed Sci. Technol. 146, 289-301.

Johnson, K.A., Johnson, D.E., 1995. Methane emissions from cattle. J. Anim. Sci. 73 2483-2492.

Khattab, H.M., Gado, H.M., Kholif, A.E., Mansour, A.M., Kholif, A.M., 2011. The potential of feeding goats sun dried rumen contents with or without bacterial inoculums as replacement for berseem clover and the effects on milk production and animal health. Int. J. Dairy Sci. 6, 267-277.

Kholif, A.E., Baza-García, L.A., Elghandour, M.M.Y., Salem, A.Z.M., Barbabosa, A., Dominguez-Vara, I.A., Sanchez-Torres, J.E., 2016. In vitro assessment of fecal inocula from horses fed on high-fiber diets with fibrolytic enzymes addition on gas, methane, and carbon dioxide productions as indicators of hindgut activity. J. Equine Vet. Sci. 39, 44-50.

Kholif, A.E., Elghandour, M.M.Y., Rodríguez, G.B., Olafadehan, O.A., Salem, A.Z.M., 2017. Anaerobic ensiling of raw agricultural waste with a fibrolytic enzyme cocktail as a cleaner and sustainable biological product. J. Clean. Prod. 142, 2649-2655.

Lewis, G.E., Sanchez, W.K., Hunt, C.W., Guy, M.A., Pritchard, G.T., Swanson, B.I., Treacher, R.J., 1999. Effect of direct-fed fibrolytic enzymes on the lactational performance of dairy cows. J. Dairy Sci. 82, 611-617.

McGinn, S.M., Beauchemin, K.A., Coates, T., Colombatto, D., 2004. Methane emissions from beef cattle: effects of monensin, sunflower oil, enzymes, yeast, and fumaric acid. J. Anim. Sci. 82, 3346-3356.

Morsy, T.A., Kholif, A.E., Kholif, S.M., Kholif, A.M., Sun, X., Salem, A.Z., 2016. Effects of two enzyme feed additives on digestion and milk production in lactating Egyptian buffaloes. Ann. Anim. Sci. 16, 209-222.

Newbold, C.J., Rode, L.M., 2006. Dietary additives to control methanogenesis in the rumen. Int. Congr. Ser. 1293, 138-147.

Nguyen, T.L.T., Hermansen, J.E., Mogensen, L., 2010. Environmental consequences of different beef production systems in the EU. J. Clean. Prod. 18, 756-766.

NRC, 1985. Nutrient Requirements of Domestic Animals. National Research Council Washington, DC, USA.

Polyorach, S., Wanapat, M., Cherdthong, A., 2014. Influence of yeast fermented cassava chip protein (YEFECAP) and roughage to concentrate ratio on rumina fermentation and microorganisms using in vitro gas production technique. Asian Australas. J. Anim. Sci. 27, 36-45.

Rodriguez, M.P., Mariezcurrena, M.D., Mariezcurrena, M.A., Lagunas, B.C. Elghandour, M.M., Kholif, A.M., Kholif, A.E., Almaráz, E.M., Salem, A.Z., 2015. Influence of live cells or cells extract of Saccharomyces cerevisiae on in vitro gas production of a total mixed ration. Ital. J. Anim. Sci. 14, 3713.

Rojo, R., Kholif, A.E., Salem, A.Z.M., Elghandour, M.M.Y., Odongo, N.E., de Oca, R.M., Rivero, N., Alonso, M.U., 2015. Influence of cellulase addition to dairy goat diets on digestion and fermentation, milk production and fatty acid content. J. Agric Sci. 153, 1514-1523.

Salem, A.Z.M., Alsersy, H., Camacho, L.M. El-Adawy, M.M. Elghandour M.M.Y. Kholif, A.E., Rivero, N., Alonso, M.U., Zaragoza, A., 2015a. Feed intake, nutrient digestibility, nitrogen utilization, and ruminal fermentation activities in sheep fed Atriplex halimus ensiled with three developed enzyme cocktails. Czech J. Anim. Sci. 60, 185-194.

Salem, A.Z.M., Elghandour, M.M.Y., Kholif, A.E., Odongo, N.E., Jiménez, F.J., Montesde-Oca, R., Domínguez, I.A., Dibarrat, J.A., 2015b. The effect of feeding horses a high fiber diet with or without exogenous fibrolytic enzymes supplementation on nutrient digestion, blood chemistry, fecal coliform count, and in vitro fecal fermentation. J. Equine Vet. Sci. 35, 735-743. 
Salem, A.Z.M., Elghandour, M.M.Y., Kholif, A.E., Barbabosa, A., Camacho, L.M., Odongo, N.E., 2016. The effect of feeding horses a high fiber diet with or without live yeast cultures supplementation on feed intake, nutrient digestion, blood chemistry, fecal coliform count and in vitro fecal fermentation. J. Equine Vet. Sci. 39, $12-19$.

SAS, 2002. User's Guide: Statistics, Version 9.0. SAS Institute, Cary, NC.

Slade, E.M., Riutta, T., Roslin, T., Tuomisto, H.L., 2016. The role of dung beetles in reducing greenhouse gas emissions from cattle farming. Sci. Rep. 6, 18140 http://dx.doi.org/10.1038/srep18140.

Steel, R.G.D., Torrie, J.H., 1980. Principles and Procedures of Statistics. A Biometrical Approach, second ed. McGraw Hill Inter. Book Co, Japan, Tokyo.

Stewart, C.S., Flint, H.J., Bryant, M.P., 1997. The rumen bacteria. In: Hobson, P.N., Stewart, C.S. (Eds.), The Rumen Microbial Ecosystem. Chapman and Hall, London, UK, pp. 10-72.

Theodorou, M.K., Williams, B.A., Dhanoa, M.S., McAllan, A.B., France, J., 1994 A simple gas production method using a pressure transducer to determine the fermentation kinetics of ruminant feeds. Anim. Feed Sci. Technol. 48, $185 \mathrm{e} 197$. Valdes, K.I., Salem, A.Z.M., López, S., Alonso, M.U., Rivero, N., Elghandour, M.M.Y. Domínguez, I.A., Ronquillo, M.G., Kholif, A.E., 2015. Influence of exogenous enzymes in presence of Salix babylonica extract on digestibility, microbial protein synthesis and performance of lambs fed maize silage. J. Agric. Sci. 153, $732-742$.

Vallejo, L.H., Salem, A.Z.M., Kholif, A.E., Elghandour, M.M.Y., Fajardo, R.C., Rivero, N., Bastida, A.Z., Mariezcurrena, M.D., 2016. Influence of cellulase or xylanase on the in vitro rumen gas production and fermentation of corn stover. Indian J. Anim. Sci. 86, 70-74.

Van Soest, P.J., Robertson, J.B., Lewis, B.A., 1991. Methods for dietary fiber, neutral detergent fiber, and non-starch polysaccharides in relation to animal nutrition. J. Dairy Sci. 74, 3583-3597.

Wiedemann, S.G., Mcgahan, E.J., Murphy, C.M., 2017. Resource use and environmental impacts from Australian chicken meat production. J. Clean. Prod. 140, 675-684. 